\title{
A Transient Transition: the Cultural and Institutional Obstacles Impeding the Northern Ireland Women's Coalition in its Progression from Informal to Formal Politics
}

Cera Murtagh

Centre for Advancement of Women in Politics

School of Politics and International Studies, Queens University Belfast

Occasional paper \# 12

February 2007

(C) Cera Murtagh and Centre for Advancement of Women in Politics, School of Politics, International Studies and Philosophy, Queens University, Belfast

Series editor: Karen Ross

ISBN No: 0853899126 


\section{Introduction}

Democracy in Northern Ireland constitutes a contested concept. The possibility of an integrated polity with which democracy is normally associated appears to be precluded by the national divisions riving society. In the context of relatively intractable conflict engendered by competing nationalisms, debate of democracy has been largely restricted to discussion of peace and conflict resolution, and solutions focused exclusively upon the issues central to the conflict - the national divide and the region's constitutional future. The democratic model adopted after devolution in Northern Ireland, consociation, arises from this perspective of conflict management via formal politics. Rather than attempting to transcend divisions, generate homogeneity or exclude extremes, consociation operates from a realistic recognition of society's fragmentation and an appreciation of its dominant discourses of nationalism, conflict and realism. Through comprehensive inclusion, proportionate accordance of governing power to each community and safeguards of group rights and interests, it seeks to secure negative peace and group accommodation via elite persuasion.

However within the informal sphere of Northern Irish politics democracy warrants far broader connotations, diverging from such singular focus on competing national factions and constitutional disputes. In particular, the women's movement has often displayed alternative assumptions and employed radically different means in striving towards a more peaceful, democratic society. While most facets of the movement conform to society's sectarian structure, an element of its networks has always existed which has periodically demonstrated the capacity to overcome national divisions and mobilise across differences in pursuit of common objectives. Such collectives embody the principles of transversal politics, an alternative political ethos characteristic of heterogeneous coalitions which prizes openness, dialogue and unity of purpose amongst diverse identities. It thus models a form of democracy distinct from that conventionally espoused within formal politics in Northern Ireland. This paper refers to this component of the movement as 'the transversal women's movement'.

Despite conventionally occupying the informal sphere of grassroots, community and local politics, the transversal women's movement has evidenced its capacity to transcend these boundaries and emerge upon the formal political arena. With the onset of devolution the movement exhibited vital agency and seized the opportunity to assume their position within the new political institutions of Northern Ireland. Though a momentous achievement however, this transition was not sustained. Just as both agency and political opportunity structure underlie the movement's 
conversion to the formal political scene, political obstacles can account for its decline. While the transversal movement possesses sufficient civic space to operate within the informal arena, the consociational institutions in place in Northern Ireland afford it little political space in which to develop and endure. The bipolar structure seeks to provide a mirror-image of society, enshrining the rights and interests of its two distinct communities. Such a system inevitably grants institutional expression to the pre-existing political discourses of the divided society, connoting the prevailing ideologies which inform political interchange. ${ }^{1}$ The transversal women's movement thus failed to sustain their transition to formal politics largely due to structural and cultural constraints engendered by the inimical discourses of nationalism, conflict and realism, and further reinforced by the consociational system.

This paper is structured in four parts. Part one introduces and theoretically explores the central concepts of this paper - transversalism and consociation. Part two depicts the NIWC's formation, transition to the formal arena and its political course therein. Part three examines the direct and indirect structural barriers while part four portrays the conflict between the established discourses of Northern Ireland politics, represented within the consociational institutions, and those of transversalism.

\section{Theoretical Framework}

Throughout its history politics in Northern Ireland has been effectively shaped by the dispute between its two principal national communities and dominated by the question of conflict resolution. A Democratic deficit thus forms a permanent feature of its formal politics in terms of representation of the public's needs and interests, women particularly bearing the brunt of its inadequacies. However, far from succumbing to passive victim-hood, women have exhibited remarkable agency, seizing power for themselves on their own terms - within the informal arena. Moreover, collectives within the women's movement have episodically employed their own distinctive style of politics in response to these undemocratic conditions. Transversal politics constitutes one such form of feminist political organisation. This section examines transversalism and consociation in theoretical terms and exposes the fundamental divergences between each theory's assumptions concerning democracy in divided societies.

\footnotetext{
1 Thomas \& Wareing, 1999, p. 191.
} 


\section{Politics in Northern Ireland}

\section{Formal Politics, Women and the Democratic Deficit}

Since 1922 formal politics in Northern Ireland has been largely determined by the all-encompassing rivalry between nationalism and unionism and effectively dominated by the constitutional question. In this contested territory the issues surrounding the relatively uncertain constitutional future of the region permeates every aspect of institutional politics. Political parties approximate the national cleavage existing within society as voter preferences are determined largely on the basis of the party's constitutional stance, precluding swing voting to any significant degree. ${ }^{2}$ This pattern reduces parties' incentives towards moderation or attention to issues other than those concerning the struggle for either a united Ireland or maintained union with Britain. In this sense, many non-sectarian social issues such as health, welfare and education, the so-called 'bread and butter issues', ${ }^{3}$ are often neglected by politicians, subordinated to the national question. This renders a severe disconnect between citizens and the political system, known as the democratic deficit. Such marginalisation doubly afflicts women, to whom those basic welfare issues remain more pertinent, to which the findings of the Opsahl Commission, an independent citizens' inquiry conducted from 1992-93 attest. ${ }^{4}$ The gravity of the constitutional question and national conflict has particularly discriminated against women's rights issues, effectively legitimising their political bypass. Furthermore women have historically been vastly underrepresented in Northern Ireland's formal politics. ${ }^{5}$ Political parties have additionally displayed reluctance to promote women as candidates for election or higher positions within party ranks, acting as gatekeepers to their entry. ${ }^{6}$ Moreover the conflict ensuing from this territorial dispute remains an inseparable dimension of politics. In fact Wilford refers to Northern Irish politics as a veritable "proxy war" in which certain parties retain strong links with paramilitary organizations and power is perceived as zero-sum, one side's loss amounting to the other's gain. ${ }^{7}$ Such an apparently undemocratic, male-dominated and confrontational system not only inhibits those women willing to participate but deters the majority from the very consideration of involvement.

McGarry in McGarry (ed.), 2001, p. 116.

Wilford in Lovenduski \& Norris, 1996, p. 55.

Hinds, 1999, p. 112.

Brown et al. 2002, p. 76.

Wilford in Fearon, 1996.

Wilford in Lovenduski \& Norris, 1996, p. 43- 44. 


\section{Women and the Formal-Informal Parallel}

Women's relative absence up to recent years from the formal political scene contrasts sharply with their plurality within the informal political sphere of grass-roots, voluntary and community organisations, with over 1000 women's groups in existence in Northern Ireland today. ${ }^{8}$ Far from crossing over however, these dual spheres remain considerably autonomous, each taking place according to Galligan and Wilford, "within the structures of parallel universes". ${ }^{9}$ Moreover this distinction is highly gendered as informal political space remains manifestly feminised and formal political space tangibly masculinised. This apparently contradictory pattern of women's peripheral presence within formal politics yet dominance amongst fluid networks and short-lived groups ${ }^{10}$ becomes more comprehensible in the context of the democratic deficit outlined above plus the national conflict which has shaped Northern Irish politics.

\section{Transversal Politics}

\section{Coalition Politics}

Della Porta and Diani define social movements as, "informal networks based on shared beliefs and solidarity, which mobilise about conflictual issues through the frequent use of various forms of protest." 11 The women's movement in Northern Ireland thus refers to women's collective mobilisation as women within such extra-institutional, informal spaces from the early 1970s. Moreover, strands of this movement have periodically been informed by the principles of transversal politics. First coined by Nira Yuval-Davis, and used synonymously with coalition and alliance politics, this term refers to the formation of alliances between women of diverse identities and distinct national communities. ${ }^{12}$ Cockburn identifies such alliances as based upon common principles and objectives rather than common identity, as identities are not fixed or singular but multiple and apt to shift over time. ${ }^{13}$ The boundaries of these coalitions are therefore established, as Yuval-Davis articulates, "not in terms of 'who' we are but in terms of what we want to achieve." ${ }^{14}$ It thus allows women of distinct national communities or contrary political beliefs to work together for a shared purpose.

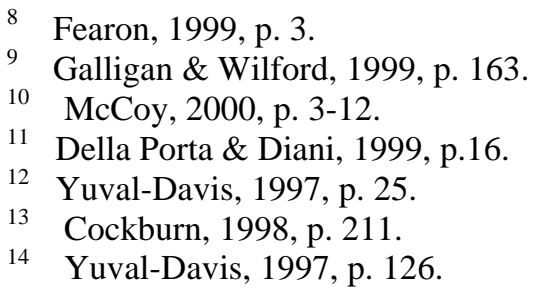


Openness, Dialogue and Participatory Democracy

Such diverse coalitions refrain from espousing one unified stance on issues for which such consensus is impossible, for example regarding the constitutional future of an nationally divided territory. Transversal theorists rather emphasise the value of dialogue in debate through which knowledge is acquired and perceptions modified. ${ }^{15}$ Endeavours must be made to empathise with the perspective of the other side without forfeiting one's one identity, through a process of 'rooting' and 'shifting'. ${ }^{16}$ Each participant to the dialogue remains rooted in her own identity and community membership, while simultaneously shifting to place herself in the position of those of an alternative stance and viewing the situation from her standpoint. Transversal politics arises from the school of second wave feminism which advocates non-hierarchical, bottom-up activism, termed participatory democracy ${ }^{17}$ and also deliberative or antagonistic democracy. 18 Through democratic process at the micro-level solutions become apparent and people empowered, their political fates no longer determined by belligerent elites and paramilitaries. This power is positive-sum in essence, a capacity as opposed to an oppressive force.

The Practice of Transversal Politics within the Women's Movement While much of the women's movement has existed within the established cleavage of society, since its origins many organisations have effectively embodied the principles of transversalism, withstanding the divisive potential of diversity. The Northern Ireland Women's Rights Movement, Women's Resource and Development Agency and Women's Support Network provide ample illustration of this ethos, each open to women of all denominations and national allegiances and refraining from adopting a definite constitutional position. ${ }^{19}$ Furthermore, much trans-community activism has been born out of necessity over practical, material issues of universal concern to women across the region. The Mothers of Belfast campaign in which women from both communities converged in protest against the government's cessation of free school milk furnishes an example of such joint action. ${ }^{20}$

15 Roulston, 2000, p. 41.

16 Yuval-Davis, 1997, p. 130

17 Roulston, 2000, p. 26.

18 Porter 2000, p. 157.

19 McWilliams, 1995, p.30.

20 McWilliams, 1995, p. 22. 


\section{Consociational Democracy}

\section{Theoretical Underpinnings}

The constitution of the Good Friday Agreement of 1998 provided for an elected 108 member Power-Sharing Assembly with executive and legislative authority. ${ }^{21}$ The structure of this Assembly was based upon the model of consociational democracy as advocated by Arend Lijphart, with all elected parties of both unionist and nationalist denomination effectively comprising two distinct blocs and sharing power proportionately. Lijphart maintains that societal division and democracy can be reconciled through consociation. ${ }^{22}$ Rather than focus solely upon the individual as the primary unit of the polity however as in conventional liberal democracy, consociation necessitates recognition of society's distinct groups and cleavages and acceptance of these segmental features as the stable building blocks for the regime. ${ }^{23}$ Lijphart thus endorsed political cooperation of segmental elites as a means to group accommodation and consensus. The system should assume the form of a "grand coalition" in which the political leaders of each bloc share power in governing the region. ${ }^{24}$ In a polity fragmented along national lines, where widespread consensus and social homogeneity are absent, representation of the people as a whole via the majority proves unfeasible, resulting in majority tyranny. ${ }^{25}$ Consociation is therefore designed to ensure group rights and proportional representation through protective mechanisms. This form of governance operates from a realistic appreciation of the sectarian divisions of society and focuses on conflict management and peaceful coexistence as opposed to integration.

\section{Transversal Politics and Consociation: An Incompatible Coupling?}

Theoretically, consociation and transversalism present two fundamentally distinct approaches to democracy in divided societies. Transversal politics prizes societal plurality, viewing communities as heterogeneous entities, comprising individuals with multiple identities. ${ }^{26}$ Consociation alternatively takes the group as opposed to the individual as its primary focus. It holds identity, particularly that of nationality, to be relatively fixed and essential and national blocs largely homogenous, thus endorsing

21 http://archive.ofmdfmni.gov.uk/publications/agreement/3.htm

22 Lijphart, 1977, p. 1

23 McGarry \& O’Leary, 1990, p. 282.

24 Lijphart, 1977, p. 25.

25 Lijphart, 1984, p. 23.

26 Roulston in Galligan et al, 1999, p.14. 
their segregation within the political system in order to grant political expression to community rights and identity. By thus institutionalising national identity however, consociation imposes a 'one or the other' categorisation on individuals and essentially grants priority to national identity, allowing little space for the expression of alternative forms such as gender. Furthermore, unlike transversalism, consociation enshrines a 'negative' form of peace, focusing on the separation of conflicting groups as opposed to a positive approach which seeks to generate a more integrated, just society through civic relationships. ${ }^{27}$ Finally, while transversal politics advocates a bottom-up approach to democracy, with civil society at its foundation, consociation prescribes a distinctly top-down method, elites constituting the central protagonists. It relies heavily upon the ability of the leaders of each segment to control their 'followers' in accommodation of the other side. ${ }^{28}$ In stark contrast transversalism espouses participation, fair process and cross-community confidence building through interpersonal relationships as the means towards a more democratic society. Thus emerges a disparity between the underlying assumptions of each theory in terms of democracy and post-conflict transition in divided societies.

\section{The Informal-Formal Transition}

As the women's movement has advanced over the last three decades in Northern Ireland, its focus has progressively shifted from civic, social and economic to political rights. Any accurate chronology of the movement however depicts, not a linear development but a tumultuous narrative punctuated by a series of divisions, reflective of its encompassing political environment. Amidst these rifts however, some space has intermittently been secured for united action. This transversal space distinctly manifested with the dawn of devolution. Women recognised their historic opportunity to straddle the informal-formal gap and enter constitutional politics in the form of a women's political party.

\section{Transcending the Informal-Formal Divide}

\section{Impetus for Transition}

The women's movement boasts an immense contribution to civil society in Northern Ireland, largely underscored by their widespread disinclination towards hierarchical formal politics. Despite this fact however, real power to affect political change ultimately lies within the formal political sphere.

27 Lijphart, 1977, p. 47.

28 Kellas, 1998, p. 183. 
Fearon thus owns that, "Other non-institutional ......activities are empowering to the individual but the ability to exert influence and assert change over and for others is limited". ${ }^{29}$ This limited capacity became apparent during the peace process of the 1990s in which negotiations largely took place behind closed doors between the two governments, politicians and paramilitaries, relatively divorced from civil society. Such inaccessibility proved particularly disempowering for women, many of whom possessed a wealth of experience in political activism to contribute to the process. ${ }^{30}$ Thus following the announcement of all-party talks to begin in 1996 with a view towards a peace agreement, the centrality of the constitutional arena to the negotiations became all the more apparent. Rather than remain external to the process however women pragmatically chose to adjust their style and scale of political engagement and transcend the boundaries of the informal realm.

\section{Political Opportunity Structure}

Women within the movement were furthermore aware of the momentous opportunity for entry to the formal sphere presented by devolution and the forthcoming new constitution. Social Movement theorists determine 'political opportunity structure', the degree of openness of a political system to a movement's demands, to be vital to its effectiveness. ${ }^{31}$ Dobrowolsky likewise identifies "state reconfiguration" as a result of constitutional change as a formidable opportunity to women's movements to intervene at the foundational stage of institutional formation. ${ }^{32}$ Thus women in Northern Ireland seized the unprecedented chance to enter at the point of conception, starting from scratch prior to rigid institutionalisation of norms.

\section{The Northern Ireland Women's Coalition}

\section{Formation}

The realisation that their input to the impending agreement from the informal sector would be minimal functioned as a mobilising force spurring women from several organisations to converge in discussion of the issue. Comprehending political parties' unresponsiveness to lobbying on the issue as an indication of their level of commitment to women's inclusion and given the party-centered nature of the process, these women faced no

29 Fearon, 1996.

$30 \quad$ Sales, 1997, p. 200.

31 Galligan, 1998, p. 10.

32 Dobrowolsky, 2003, p. 117. 
alternative but to form their own party to contest the upcoming elections to the Forum for Political Dialogue and Multi-Party Peace Talks. ${ }^{33}$ In April 1996 the NIWC was thus formed out of sheer necessity, from the preexisting networks of the women's movement. An amalgam of women from distinct religious and national allegiances and an array of different activism backgrounds, the NIWC assumed the form of a non-hierarchical coalition, rather than a conventional centralised party - an essentially 'transversal' party. Espousing inclusion, equality and human rights as its three core principles, ${ }^{34}$ the NIWC advocated a radically new type of politics. With an informed belief in the power of civic engagement to foster greater social cohesion, it intended to transmit the lessons of the community into formal politics thereby further integrating these two spheres. ${ }^{35}$ Though a political party, the NIWC therefore sought to remain true to its grassroots origins. With regard to the constitutional future of Northern Ireland, while its members individually harboured divergent national identities, allegiances and aspirations, the Coalition assumed an open position. ${ }^{36}$

Progression within Formal Politics: From the Peace Talks to the Assembly After much lobbying by the NIWC, in accordance with the interests of the smaller parties, an unusual form of List system Proportional Representation (PR) with regional top-up was adopted for the elections to the Forum and Multi-party talks in 1996. It functioned so that each of the ten parties with the most votes across Northern Ireland elected another two representatives, presenting the NIWC with a crucial opportunity at the entry level of formal politics. ${ }^{37}$ It gained two seats on account of this top-up formula. ${ }^{38}$ Delegates Monica McWilliams, a Catholic and Pearl Sagar, a Protestant, assumed these seats at the Forum and later at the Talks where they negotiated with other parties in the formulation of the Good Friday Agreement. Confronted with the less conducive electoral system of PR with Single Transferable Vote (STV), it secured two Members of Legislative Assembly (MLAs), Monica McWilliams and Jane Morrice, a Protestant, to the Northern Ireland Assembly in $1998 .^{39}$ However, the party's mandate declined considerably in the years following the Agreement's

33 Fearon, 1999, p. 3-11.

34 NIWC 1998 Northern Ireland Assembly Election Manifesto - A New Voice for New Times.

35 Ridden , 2001, p. 115.

${ }^{36}$ NIWC 1998 Northern Ireland Assembly Election Manifesto

37 http://www.ark.ac.uk/elections/ff96.htm

38 Ibid.

39 http://www.ark.ac.uk/elections/fa98.htm 
implementation, culminating in its loss of both Assembly seats in the 2003 election, scraping only $0.8 \%$ of the vote, a $50 \%$ drop from its 1998 performance. ${ }^{40}$ Similarly its last enduring foothold in the formal sphere dissipated in 2005 when its one remaining Councillor, Patricia Wallace lost her seat. ${ }^{41}$ With no remaining elected representatives the party disbanded in May 2006 after ten years in operation.

\section{Structural Barriers}

This section presents the institutional obstacles confronting the NIWC within formal politics in Northern Ireland. It analyses several features of the particular consociational institutions in terms of their direct and indirect incompatibility with the party's distinctive features and principles.

\section{Direct Structural Barriers}

\section{Electoral Systems}

Preceding impediments to emerge following its entry to the Assembly, the primary obstacle facing the NIWC manifested within that very election process. While the list-system of proportional representation (PR) with regional top-up chosen for the Forum elections in 1996 worked to the advantage of the NIWC, ${ }^{42}$ the preferential system of PR with Single Transferable Vote (PR-STV) adopted for the 1998 Assembly election indisputably disadvantaged the party. ${ }^{43}$ Horowitz outlines the structural handicaps imposed by such a system in terms of the NIWC's size, crosscommunity nature and the geographical distribution of its support base. ${ }^{44}$ With respect to size, under STV it is relatively easy for parties to win a seat, thus advantaging dominant parties and leaving little space for a new party to make a break-through. ${ }^{45}$ This system also promotes potential electoral pacts between parties promoting similar policies, thus marginalising the NIWC as a party occupying a small cross-communal territory with limited capacity to form cross-party alliances. Monica McWilliams criticised this practice in the run-up to the 2003 Assembly elections in which SF and the UUP appealed to voters to transfer firstly to nationalist and unionist candidates

\footnotetext{
40 http://www.ark.ac.uk/elections/fa03.htm

41 http://www.ark.ac.uk/elections/flg05.htm

42 Dobrowolsky, 2002, p. 314.

43 Wilford \& Wilson, 2006, p. 23.

44 Horowitz, 2002, p. 208.

45 Horowitz, 1993, p. 180.
} 
respectively and then to pro-agreement candidates. ${ }^{46}$ Horowitz hence identifies STV as "a system perfectly compatible with the maintenance of ethnically based parties and not particularly supportive of multi-ethnic coalitions." ${ }^{47}$ It evidently renders vote transfers across ethnic blocs, and between ethnic and non-ethnic parties highly unlikely. In terms of Local Government this feature of the electoral system clearly contributed to the NIWC's loss of Councilor Wallace's seat in North Down Council in 2005 where she faced competition from eight DUP candidates, one of whom gained very few first preferences but almost all of the transfers. ${ }^{48}$ Furthermore PR-STV damaged the NIWC in terms of its territorial constituency basis, given the high regional dispersion of the party's supporters. $^{49}$ The particular electoral system adopted thus formed a significant factor in the party's polling performances.

\section{The Voting System within the Assembly: Designation}

Having gained entry to the Assembly despite such inauspicious electoral circumstances, the NIWC immediately encountered further institutional marginalisation. In order to preserve the principles of cross-community consensus and guarantees upon which the institutions were founded, elected representatives were obliged to register at Stormont as 'nationalist, unionist or other' for votes to be counted in this respect. ${ }^{50}$ Key decisions within the Assembly and Executive required either 'parallel consent', connoting majorities within both nationalist and unionist blocs or a 'weighted majority' of at least $60 \%$ of all voting members plus $40 \%$ of each bloc. ${ }^{51}$ Furthermore the Agreement entails 'petition procedures' enabling thirty or more MLAs to present a 'petition of concern' on any vote taken in the Assembly. ${ }^{52}$ In this sense the institutions ensure a group veto to each community, ${ }^{53}$ thus upholding the Agreement's central tenet of 'parity of esteem'. However, in so doing, cross-community parties which defy dualistic categorisation are relegated to the periphery in terms of decision making. Ridden attests to this inequality stating that although the NIWC could influence debate, "their votes can have little or no impact on the

\footnotetext{
46 Moriarty, 2003.

Horowitz, 2001, p. 100.

Interview with Margaret Ward.

49 Horowitz, 2002, p. 208.

50 The Belfast Agreement 10 April 1998, p. 8.

Horowitz, 2002, p. 194.

52 http://www.answers.com/topic/northern-ireland-assembly

53 McGarry \& O’Leary, 2006(1), p.45
} 
outcome of contested legislation". ${ }^{54}$ With respect to certain decisions the votes of the excluded 'others' thus simply do not count. Additionally, their collective number grants them little leverage within the Assembly. They can be easily out-voted by any majority and lack sufficient numbers to elicit a petition of their own. ${ }^{55}$ Such marginalisation not only disempowered the NIWC in real terms but also in terms of public perception, harming its purported image as an effective agent for political change. Even prominent advocates of consociation, John McGarry and Brendan O’Leary, admit this inherent discrimination, owning, "There is an incentive for voters to choose nationalists or unionists, as members from these groups will, ceteris paribus, count more than 'others' or be more pivotal."56 However, McGarry justifies such double standards in his earlier work, claiming, "The 'Others', however, have not been at the heart of the conflict. It is therefore not surprising if they are not at the heart of the resulting pacts, though it is not accurate to claim that they are excluded from the Agreement.”57 This statement reflects the inimicality of consociation to transformation of the established configuration of power plus its bias against non-ethnic parties. This system effectively presents cross-community parties as political lightweights, ultimately less significant and effectual than their nationally aligned counterparts. The NIWC initially responded to this rigid designation system by defining itself as 'inclusive other'. ${ }^{58}$ In 2001 however, in reaction to an institutional crisis and the potential collapse of the Agreement, the party's two MLAs pragmatically re-designated as one 'unionist' and one 'nationalist', in order to ensure the return to office of the First Minister and Deputy First Minister. ${ }^{59}$ Thus the NIWC were compelled to compromise their transversal principles to adapt to their pillarised political environment.

\section{Indirect Barriers: Polarization and Shifting Space}

Throughout the course of devolution the complex political arena of Northern Ireland remained wrought not only with divergent political nationalisms simmering beneath the surface but also with fear and mistrust of the other side's true intentions. The continual crises and suspensions that marked its existence thus appear unremarkable. Within such a fractured political landscape, the new-founded transversal space claimed by the

Ridden, 2001, p. 112.

McGarry, 2004, p. 271.

McGarry \& O’Leary, 2006(2), p. 272.

McGarry, 2004, p. 272.

58 Fearon \& McWilliams, 2000, p. 68.

59 'Looking Back... Looking Forward', Northern Ireland Women's Coalition Annual Report 2002. 
NIWC in 1998 dissipated as the climate ultimately became more polarized, culminating in its loss of both seats in the 2003 Assembly election. This election which elicited a dramatic reconfiguration saw the 'extremes', DUP and SF assume majority status in their respective blocs. Various theories exist to explicate this phenomenon, including voter disillusionment with the Agreement and the new appeal of the DUP and SF to the middle-ground electorate. An interaction of these factors undoubtedly underlies this electoral shift, extensive analysis of which exceeds the scope of this paper. A definite attitudinal regression is apparent however from the impetus for change which accompanied the Agreement, to a more defensive mentality. This outlook manifested in voting behaviour in these elections which Wilford asserts, "became a battleground between the political heavyweights" resulting in the current four party dominance. ${ }^{60} \mathrm{He}$ documents such "defensive voting", for example, on the part of unionists, motivated by a sense of insecurity, ${ }^{61}$ voting DUP in response to the growth of SF, as if based on a version of prisoner's dilemma. ${ }^{62}$ Similarly, Ann Hope recounts that while canvassing for the NIWC in 2003 many voters who had previously given it their first preference, now perceiving the political stakes to be higher and the situation more volatile, stated their intention to vote for one of the four major parties. ${ }^{63}$ Motivated additionally by the characteristic instability of the institutions, under suspension at the time, and the uncertainty of their future, many voters undoubtedly dealigned from the NIWC in response to the specific unstable circumstances in which many felt only the major parties could play a role. This climatic shift from the optimism and opportunity for change heralded by the signing of the Agreement to such cautionary insularity evidently formed a determining factor in the NIWC's loss of political space and thus power.

\section{Conflicting Discourses}

This section explores the interaction between the transversal discourses of the NIWC and the traditional political discourses of currency in Northern Ireland. It examines the dominant discourses of nationalism, conflict and realism and their institutionalisation within the consociational system. This section displays the contradictory nature of this political culture in relation

\footnotetext{
60 Interview with Wilford.

61 Interview with Wilford.

62 Horowitz, 2001, p. 101.

63 Interview with Ann Hope.
} 
to that advocated and internally practiced by the NIWC. It thus illustrates the consequences for the NIWC of such a normative clash.

\section{Traditional Political Discourses in Northern Ireland}

\section{Competing Nationalisms}

The most pervasive discourse operating in Northern Ireland politics, particularly since the late 1960 s, is that of competing nationalisms. A schism divides society broadly into two distinct communities possessing divergent and thus competing national allegiances and often aspirations, both of which evidently cannot be accommodated within the political system. Though such a clear-cut binary division patently represents an over-simplification of attitudes and identities at the micro-level, at the macro political level this cleavage nevertheless remains determining. Formal elite politics approximates the dualistic segregation of society to such an exaggerated extent that one's stance on the constitutional question constitutes the central axis around which all political affairs revolve. Politics thus becomes imbued with an 'us versus them' oppositional discourse. Nationalism, as Wilford asserts, "is propelled by an 'us and them', insider/outsider, inclusive/exclusive dynamic, (and).. can be carried to exaggerated and dangerous extremes in divided societies." ${ }^{64}$ Northern Ireland provides ample illustration of such extremes, as preservation of each 'nation' and its respective cause is sought through segregation of 'us' from 'them', not only artificially fixing identity and homogenising each group but also objectifying and exploiting 'the Other' ${ }^{65}$ Within such hostile conditions, difference becomes feared and treated as a negative antagonism. ${ }^{66}$ While differences between groups are accentuated by national elites, solidarity and unity within groups are prized as bolstering the potency of their cause. Elites seek to further consolidate their agenda by assuming a highly fixed stance and steadfast, intransigent negotiating style. $^{67}$

\section{Women within Nationalist Discourse}

The salience of nationalist discourse within Northern Irish politics has exerted a highly negative impact upon women's participation. Anthias and Yuval-Davis identify the various roles assigned to women within nationalist discourse, one of which is that of signifier or symbol of national

\footnotetext{
64 Wilford, 1998, p. 2.

65 Porter, 1998, p. 40.

66 Porter, 2000, p. 143.

67 McCoy, 2000, p. 20.
} 
differences. ${ }^{68}$ While men act as national agents women form the national symbols of loyalty, maternal self-sacrificing, passivity and victim-hood. ${ }^{69}$ In this sense, feminism and women's mobilisation on non-nationalist lines runs contrary to the ideologies of the nationalist movements. Rachel Ward documents this discord within the unionist movement which views feminism with grave suspicion as a rival force to its conservatism and impetus to maintain the constitutional status-quo. She deems feminism to be, "something of a dirty word in unionism", affirming, "Women are unionists first and women second." 70 The perilous position occupied by women in this discourse becomes replicated in nationalist politics and constitutes a detrimental force to all women's political participation but particularly that within transversal women's politics.

\section{Conflict and Violence}

The hostility between these two competing factions is further intensified and the political dynamics complicated by the use of violence by paramilitary groups on each side. Such violence has had a profound spill-over affect on formal politics in the region, escalating tensions and polarising allegiances. Force, utilised by these movements for the purpose of political gains, has become somewhat indivisible from constitutional politics, epitomized by Sinn Fein's alleged dual employment of 'the armelite and the ballot box'. The ubiquity of violence has infused the political arena with a masculine, martial discourse, ${ }^{72}$ as parties characteristically conduct political interchange in this aggressive style. Thus, the political territory in Northern Ireland is a contested one, offering little sanctuary to the nonconfrontational actor espousing values traditionally viewed as 'feminine' non-violence, dialogue and compromise.

\section{$\underline{\text { Realism }}$}

In such an environment of conflict between two competing nationalist groups, the discourse of realism constitutes a determining force. In a divided society in which the balance of power is unequal (historically tilted in favour the 'unionist' community) acute realism informs all political acts. Power thus manifests as a negative and zero-sum construct. ${ }^{73}$ Elites assume a causal link between their opponents' loss and their own profit and

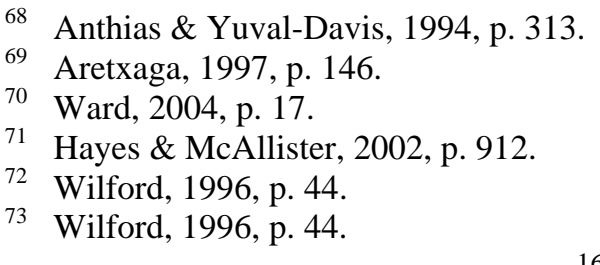


rationally calculate decisions on this basis. Furthermore, power in the militarised political arena, constitutes a gendered construct, as sectarian antagonism and the implied capacity to resort to force retain currency in elite negotiation and are often considered the most effective means to achieve their ends. Public spaces and political power in Northern Ireland have thus become highly gendered.

\section{Consociation: Institutional Recognition of Dominant Discourses}

\section{Recognition of Binary Division}

The devolved political institutions designed to regulate conflict in Northern Ireland were conceived from a realistic understanding and recognition of its bipolar sectarianism. While such a shift towards overt recognition of differences and discussion of injustices represents creates a more realistic and level playing field it also marginalises alternate sources of identity and inequality ${ }^{74}$ reaping negative affects for those actors mobilising on identities other than national. The most overt institutional manifestation of this imposed 'either/or' classification was the requirement of MLAs at Stormont to declare their national allegiance to ensure cross-community consensus. ${ }^{75}$ In so doing, consociation has not only institutionalised sectarianism by consolidating each nationalist bloc, but also privileged national identity over other sources, such as gender. ${ }^{76}$

\section{Recognition of Realism and Competing Nationalisms}

In addition to national binary opposition, consociation equally enshrines the discourse of realism. In fact, its structures are developed from an appreciation of the salience realism boasts within divided societies, prompting McGarry and O'Leary to term it, "responsible realism”. ${ }^{77}$ In recognising each community's divergent interests and assuming the capacity of each to exert hegemonic power over the other, it comprises a multitude of safeguards and minority rights. Consociation resists attempts to induce moderation or integration of group interests but alternatively acknowledges the zero-sum nature of power in the divided polity and thus includes all positions in a comprehensive yet segregated political structure. In this sense it seeks to regulate conflict rather than transcend or transform it.

\footnotetext{
74 Lijphart, 1977, p. 49.

Horowitz , 2001, p. 89.

76 Cowell-Meyers, 2003, p. 87.

77 McGarry \& O’Leary, 2006 (2), op cit, p. 254. 


\section{Transversalism: An Alternative Discourse in an Inhospitable}

\section{Environment}

Non-nationalist

The consociational institutions were thus informed by the above preexisting discourses, serving to further ingrain these dynamics in the political system as opposed to attempting their transformation. Such discourses evidently stand diametrically opposed to the transversal discourses espoused by the NIWC. Firstly, in terms of national allegiance, the NIWC represented a multi-partisan entity, contrary to the dominant bi-polar discourse of the consociational system. It prized diversity and fluidity of identity as opposed to the homogeneity and fixity of national identity institutionalised in the binary consociational structures. Furthermore, it advocated individual autonomy and freedom of allegiance, and focused on human rights and equality rather than solely national group rights. The party's most unconventional feature however, was its lack of stance on the constitutional future of Northern Ireland. While other parties defined themselves almost entirely on this issue, the NIWC contested the efficacy of political nationalism, arguing, as Roulston stipulates, "that these were out of date questions in the late twentieth century when sovereignty and statehood are being transformed and renegotiated."78 Representing members of both nationalist groups plus members of neither, it appreciated the subjectivity of each national aspiration and the irreconcilability of both in their absolute forms, alternatively advocating dialogue, and focus on 'here and now' political issues, such as welfare, health and education as opposed to unrealistic visions of the future.

\section{Non-realist}

Furthermore, the prevailing realist discourse of the political system proved inimical to the NIWC's principles of positive power. The party entered public office with a determination, not to simply defeat other parties or reproduce the existing power relations but to build alliances across parties for the advancement of its objectives. For example, on the issue of equal representation, it campaigned for greater inclusion of women in all parties, and in terms of inter-party relations, during the Forum and Multi-Party talks it often acted as a conduit between parties not yet ready to meet face to face. ${ }^{79}$ Fearon similarly documents how the NIWC's proposals during the talks, such as those on rights, were often subsumed and later reproduced in different guise by other parties. This pattern elicited little resentment from

\footnotetext{
78 Roulston, 1999, p. 9.

79 Roulston, 1999, p. 9.
} 
the NIWC however, content that such issues reached the agenda. ${ }^{80}$ Such generous, non-competitive behaviour epitomises the 'politics of care ${ }^{81}$ with which the NIWC hoped to infuse the new institutions and replace the zerosum discourse. Winning was never the NIWC's primary objective but advancing the political culture beyond this binary 'winner/loser' mentality.

\section{Consequences for the NIWC}

Opposition from Other Parties: Miscomprehension and Misrepresentation As a consequence of such incompatible discourses the NIWC encountered much miscomprehension and often outright opposition from other parties within the Assembly. Primarily, by virtue of its non-aligned constitutional stance, it evaded conventional dualistic categorisation and evoked suspicion and confusion amongst elites institutionalised by the nationalist 'either/or' discourse. Indeed, so alien were many of its transversal principles, that they were misunderstood by other elites and the media and consequently often misrepresented to the public. Given the omnipresence of the constitutional question in Northern Irish politics, the issue has almost become synonymous with politics itself. This ingrained association generates a perception of any entity which does not purport a fixed stance on the issue as apolitical, and external to serious political affairs. Thus, due to their open position the NIWC were widely portrayed as disorganised, incoherent and ineffective. Even academics such as Rachel Ward disseminate this image, alleging that the NIWC "had no clear policies and refused to be drawn on the broader issue” ${ }^{82}$ (my italics). A similarly dismissive attitude can be discerned in Seamus Mallon's (SDLP) response to the NIWC's election to the Forum,

“This won't be about setting differences aside, this will be about facing differences that we have in this community, facing them fullfrontal and dealing with those differences. What we must realise is that these negotiations which are going to take place are going to be very hard-nosed and they are going to be real..."

Many of the NIWC's peers evidently failed to take them seriously as real political players and thus depicted an image in public statements of ineffectual novices shortly to be crushed by the 'real' political game.

80 Fearon, 1999, p. 92.

81 Porter, 1998, p. 31.

82 Ward, 1997, p. 151.

83 Mallon quoted in Fearon, 1999, p. 17. 
Similarly, given the embedded nature of violence within political discourse, Wilford asserts that transversal women's bodies' association with nonviolence and compromise, "can be interpreted as a measure of powerlessness." 84 This sentiment is evident in Peter Robinson of the DUP's remarks in relation to NIWC members, "they haven't been at the forefront of the battle when shots were being fired or when the constitution of Northern Ireland was in peril." ${ }^{85}$ Such violent imagery is commonplace in political language in Northern Ireland, often used to validate political actors as credible contenders by association with the ongoing 'battle'. In this adversarial political culture Meehan affirms that, "compromise is a word that is taken to denote weakness instead of strength". ${ }^{86}$ Furthermore, the NIWC's multi-faceted, fluid character served to supplement this image of weakness, as Wilford cautions, "the power of diversity has as its mirror image and companion the powerlessness of fragmentation." ${ }^{87}$ Juxtaposed with such cohesive, internally structured and easily definable nationalist parties, the NIWC truly appeared a foreign body within the Northern Irish Assembly.

\section{Opposition from Other Parties: Nationalist Interests}

Another force fuelling such negative representations was nationalist interests. Nationally aligned parties widely perceived the NIWC as a threat to their political agendas. In congruence with nationalist discourse concerning women, the NIWC were cast as disloyal defectors from each national cause, repeatedly accused by various parties of "poaching women", ${ }^{88}$ splitting the vote and weakening their side in the 'us vs. them' constitutional struggle. McWilliams attests to this resentful suspicion, proclaiming, "We're representative of both communities - that confuses them, they don't like it, and it makes us the brunt of hatred, the brunt of venom." 89 Moreover, while the NIWC resisted participating in the other parties' competitive zero-sum game, these parties regardless viewed it as a potential rival within this limited political territory. Due to its separate party status, Brown et al identify that, "a situation arose in which other parties could attack it and its objectives with little fear of alienating their own women members." ${ }^{90}$ In this sense Sagar asserts, "I do believe that

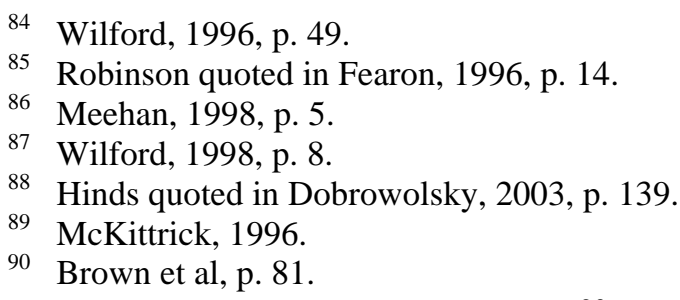


some (parties) understood us too well and encouraged misunderstanding". ${ }^{91}$ The NIWC accordingly suffered chauvinistic abuse within the political arena, most notably in the Forum where Pearl Sagar was once told to "Sit down and shut up” by Jim Rogers of the UUP, while Monica McWilliams was 'mooed at' by the DUP's Ian Paisley Junior. ${ }^{92}$ The level of toleration and legitimacy which surrounded such aggressive, misogynistic behaviour exposes the salience of regressive nationalist discourse in Northern Irish politics.

\section{Lack of Cross-Party Alliance}

Given such sectarian opposition from other parties, the potential for the cross-party alliances the NIWC had hoped to achieve remained unlikely. Despite its efforts to build bridges across entrenched party divides, other parties proved simply unwilling to move beyond their insular, sectarian positions. ${ }^{93}$ It similarly failed to generate linkages amongst women from different parties, ${ }^{94}$ a presumably more feasible feat. In fact, many women actively resented the NIWC as the 'Janey come lately's' ${ }^{95}$ monopolising media attention and overshadowing their prior progress achieved over the years. Many also begrudged its alternative feminine style of politics which they viewed as ineffectual and inappropriate to the 'hard-nosed' politics of Northern Ireland. A tradition of strong internal party discipline, and segregation informed by the nationalist and realist discourses discussed and reinforced by the consociational institutions largely precluded any crossparty women's caucus from emerging. One female SF MLA's account of her experience of being heckled in the Assembly clearly illustrates this point; "But when we were getting heckled, Iris Robinson (DUP) was in there giving it all she had.... She didn't see us as women or somebody she had empathy with - we were Sinn Fein and our gender didn't come into it." ${ }^{96}$ Gender boasts little unifying capacity in an environment where national allegiance dictates. Likewise Patricia Wallace reflects that despite private cordiality, such stringent party discipline often deterred other parties, even those of the moderate middle ground such as the Alliance, from publicly supporting the NIWC. ${ }^{97}$ Lacking the numbers, the formal

91 Email correspondence with Pearl Sagar.

92 Fearon, 1999, pp. 55-62.

93 Brown et al, 2002, p. 80.

94 Cowell- Meyers, 2003, p. 87.

95 Fearon, 1999, p. 16.

96 Ward, 2004, p. 15.

97 Interview with Patricia Wallace. 
political experience, institutionalization, and established structural power of its rival parties, the absence of cross-party support proved highly

detrimental to the NIWC.

\section{Conclusion}

The Transition: Opportunities and Obstacles

The unsteady path of transition from informal to formal politics negotiated by the 'transversal women's movement' is one evidently marked by both opportunities and obstacles. The course of the NIWC conveys a regressive sequence from the opening up of a transversal political space to the progressive contraction of that space and its eventual demise. Thus from the party's opportunistic interception within the talks process it remained prey to the variances of its volatile external environment. Though the selfempowering agency exhibited by the party predominantly underlies its political progress, inimical structure equally served to limit its advances and, in the final instance determine its fate.

\section{Obstacles to Entry, Power and Endurance}

The conflicting discourses embodied within the consociational institutions ultimately hampered the NIWC's development by three principal means - in terms of its entry to the formal arena, its power, influence and ability to maintain its position therein. Firstly, with regard to entry or transition, this paper has illustrated the negative impact of the electoral system of PR-STV adopted for the Assembly elections. Requiring relatively low numbers of votes to secure seats this system proved extremely conducive to the interests of the major parties, reflecting consociation's prioritization for inclusion of established parties as representatives of the each national bloc. This feature thus privileges nationally-aligned parties at the expense of smaller, newer and non-aligned parties such as the transversal NIWC.

Secondly, in terms of progress and power to exert influence and advance its agenda, the structure and organising principle of the consociational institutions transpired to be inhospitable to the NIWC. Founded upon recognition of the division of society into two autonomous pillars, consociation offers little accommodation to more pluralistic identities and imposes this 'either/or' distinction on all political actors. The designative voting system within the Assembly clearly reflects such enforced categorization. It essentially disempowered the NIWC as the isolated 'other', rendering its votes ineffective on crucial matters. Furthermore its public image as a credible and active political party inevitably suffered as a result. Moreover, as a new, relatively small and 
unconventional party, much of the NIWC's capacity to exercise influence depended upon its ability to build alliances and linkages with other parties. Its power to advance gender equality issues for example, would have been greatly facilitated by the development of a cross-party women's caucus. Mackay et al demonstrate by contrast, the leverage such vital linkages reaped for the Scottish umbrella body, the Scottish Women's Coordination Group, in promoting its agenda. ${ }^{98}$ However, the extreme fragmentation of Northern Irish politics rendered alliance formation a difficult task. The 'institutionalised sectarianism' and mutual mistrust between parties created little opportunity for the NIWC to generate the linkages and support networks it required to adequately promote its policies within the Assembly. Rather, the NIWC often found itself subject to harsh derision from its 'rival' parties. The established political norms of internal party discipline, interparty hostility, competitive realism and entrenched divisions, bolstered by the institutional mechanisms of consociation, furnished the NIWC with little cross-party alliance.

Finally, the endurance of the NIWC as a party within formal politics relied heavily upon its encompassing political circumstances. As illustrated, the party's elected delegates diminished progressively throughout its course. In 2006, after losing its last remaining elected representative it faced no alternative but to disband. Its diminishing mandate strongly correlates however with the increasing polarisation of Northern Irish constitutional politics. The political space it acquired during the pre-Agreement period of hope and enthusiasm shrank rapidly as the institutions staggered from crisis to crisis and tensions heightened.

Replacing that positive impetus for change prevalent in 1996 and 1998 was an atmosphere of regressive apprehension in 2003. Defensive voting and sectarian insularity characterised these elections which heralded the beginning of the end for the NIWC as it lost both of its Assembly seats. The NIWC's marginalisation within the institutions and apparent isolation from the realist nationalist game undoubtedly contributed to its sidelining at this point of constitutional crisis.

\section{A Transition Interrupted?}

The transversal women's movement has demonstrated its determinacy and transformative capacity by transcending the boundaries of informal politics amidst constraining circumstances. Its agency triumphed over these structural constraints initially as it transmitted its principles from its established civic space to this new-found political space in the form of a

\footnotetext{
98 Mackay et al, 2002 ,p. 40.
} 
transversal political party. It actively maximised this space, challenging Northern Ireland's traditional discourses of nationalism and realism plus the passive, reinforcing political roles they ascribe to women. However, the movement has failed to sustain this transition due to an interplay of cultural and structural obstacles supplemented by specific inimical circumstances. The omnipresent nationalist and realist discourses alone present major cultural impediments to transversal politics. However, granted institutional legitimacy within the consociational system, these barriers become further entrenched. Informed by these prevailing discourses consociation fundamentally contradicts the assumptions of transversalism in terms of democracy in divided societies and conflict resolution via formal politics. Furthermore, the space granted to the transversal party effectively shrank beneath the feet of its members as its time within the institutions progressed. While this polarization did not manifest as a direct result of the consociational system, its instability formed a contributory factor in the shift. Given the above obstacles, the party could not possibly withstand the loss of this space and in the final instance dissolved. Thus its transition was ultimately restricted by such structural obstructions and mutations. The political discourses of Northern Ireland's divided society, embedded within the consociational system, inevitably inhibited the NIWC's political progress and endurance, rendering the movement's transition to formal politics a transient phenomenon.

\section{References}

Anthias, Floya \& Yuval-Davis, Nira 'Women and the Nation-State' in John Hutchinson \& Anthony D. Smith (1994) Nationalism, Oxford: Oxford University Press.

Aretxaga, Begona (1997) Shattering Silence: Women, Nationalism and Political Subjectivity in Northern Ireland, New Jersey: Princeton University Press.

Brown, Alice, Donaghy,Tahyna Barnett , Mackay, Fiona \& Meehan, Elizabeth (2002) 'Women in Constitutional Change in Scotland and Northern Ireland', Parliamentary Affairs, Vol. 55, pp. 71-84.

Cockburn, Cynthia (1998) The Space Between Us: Negotiating Gender and National Identities in Conflict, London \& New York: Zed Books.

Cowell-Meyers, Kimberley (2003) 'Women in Northern Irish Politics: Gender and the Politics of Peace-Building in the New Legislative Assembly’ Irish Political Studies, 18(1), pp.72-96.

Della Porta, Donatella \& Diani, Mario (1999) Social Movements: An Introduction, Oxford: Blackwell. 
Dobrowolsky, Alexander (2002) 'Crossing Boundaries: Exploring and Mapping Women's Constitutional Interventions in England, Scotland and Northern Ireland', Social Politics, Summer 2002, pp. 293-337.

Dobrowolsky, Alexandra 'Shifting States: Women's Constitutional Organising Across Time and Space' in Lee Ann Banaszak, Karen Beckwith \& Dieter Rucht (eds) (2003) Women's Movements Facing the Reconfigured State, Cambridge: Cambridge University Press.

Fearon, Kate (ed.) (1996) 'Power, Politics, Positionings', Democratic Dialogue Papers, No.4, Belfast: Democratic Dialogue.

Fearon, Kate (1999) Women's Work: The Story of the Northern Ireland Women's Coalition, Belfast: Blackstaff.

Fearon, Kate \& McWilliams, Monica 'Swimming Against the Mainstream' in Carmel Roulston \& Celia Davies (eds.) (2000) Gender, Democracy and Inclusion in Northern Ireland, Hampshire: Palgrave.

Galligan, Yvonne (1998) Women and Politics in Contemporary Ireland: From the Margins to the Mainstream, London \& Washington: Pinter.

Galligan, Yvonne \& Wilford, Rick ‘Women’s Political Representation in Ireland' in Yvonne Galligan, Eilis Ward \& Rick Wilford (eds.) (1999) Contesting Politics: Women in Ireland North and South, Boulder: Westview Press.

Hayes, Bernadette C. \& McAllister, Ian (2002) ‘Sowing Dragon's Teeth: Public Support for Political Violence and Paramilitarism in Northern Ireland', Political Studies, Vol. 49, pp. 901-922.

Hinds, Bronagh 'Women Working for Peace in Northern Ireland' in Yvonne Galligan, Eilish Ward \& Rick Wilford (eds.) (1999) Contesting Politics: Women in Ireland North and South, Boulder: Westview Press.

Horowitz, Donald L. 'Conflict and the Incentives to Political Accommodation' in Dermot Keogh \& Michael H. Haltzel (eds.) (1993) Northern Ireland and the Politics of Reconciliation, Washington: Woodrow Wilson Centre.

Horowitz, Donald L. 'The Northern Ireland Agreement: Clear, Consociational and Risky' in John McGarry (ed.) (2001) Northern Ireland and the Divided World: The Northern Ireland Conflict and the Good Friday Agreement in Comparative Perspective, Oxford: Oxford University Press.

Horowitz, Donald L. (2002) 'Explaining the Northern Ireland Agreement: the Sources of an Unlikely Constitutional Consensus' in British Journal of Political Science, 32(2), pp. 193-195.

Kellas, James G. (1998) The Politics of Nationalism and Ethnicity, $2^{\text {nd }}$ Ed., London: Macmillan. 
Lijphart, Arend (1984) Democracies: Patterns of Majoritarian and Consensus Government in Twenty-One Countries, New Haven: Yale University Press.

Lijphart, Arend (1977) Democracy in Plural Societies: A Comparative Exploration, New Haven \& London: Yale University Press.

'Looking Back... Looking Forward', Northern Ireland Women's Coalition Annual Report 2002.

Mackay, Fiona, Meehan, Elizabeth, Donaghy, Tahyna Barnett \& Brown, Alice (2002) 'Women and Constitutional Change in Scotland, Wales and Northern Ireland', Australian Parliamentary Review, 17(2), pp. 35-54.

McCoy, Grainne 'Women, Community and Politics in Northern Ireland' in Carmel Roulston \& Celia Davies (eds.) (2000) Gender, Democracy and Inclusion in Northern Ireland, Hampshire: Palgrave, p. 3-12.

John McGarry \& Brendan O’Leary (1990) The Future of Northern Ireland, Oxford: Oxford University Press.

McGarry, John 'Northern Ireland, Civic Nationalism and the Good Friday Agreement' in John McGarry (ed.) (2001) Northern Ireland and the Divided World: The Northern Ireland Conflict and the Good Friday Agreement in Comparative Perspective, Oxford: Oxford University Press.

McGarry, John 'The Nature of the Agreement' in John McGarry \& Brendan O’Leary (2004) The Northern Ireland Conflict: Consociational Engagements, Oxford: Oxford University Press, Oxford Scholarship Online. Oxford University Press. 3 August 2006, http://dx.doi.org/10.1093/0199266573.001.0001

McGarry, John \& O’Leary, Brendan (2006) 'Consociational Theory, Northern Ireland's Conflict and its Agreement. Part 1. What Consociationalists can Learn from Northern Ireland', Government and Opposition, 41(1), pp. 43-63.

McGarry, John \& O’Leary, Brendan (2006) 'Consociational Theory, Northern Ireland's Conflict and its Agreement. Part 2. What Critics of Consociation can Learn from Northern Ireland', Government and Opposition, 41(2), pp. 249-277.

McKittrick, David ‘The 'Stinking Red Herrings' Fight On’ , The Irish Independent, 09/09/96.

McWilliams, Monica (1995) 'Struggling for Peace and Justice: Reflections on Women's Activism in Northern Ireland', Journal of Women's History, 6(4), 17(1), pp. 13-39.

Meehan, Elizabeth 'Democracy Unbound' in Robin Wilson (ed.) (1998) Reconstituting Politics, Belfast: Democratic Dialogue. 
Moriarty, Gerry 'Blair Appeals to Voters to Choose the Future', The Irish Times, 25/11/03.

Porter, Elisabeth 'Identity, Location, Plurality: Women, Nationalism and Northern Ireland, in Rick Wilford \& Robert L. Miller (eds.) (1998) Women, Ethnicity and Nationalism: The Politics of Transition, London \& New York: Routledge.

Porter, Elisabeth 'Participatory Democracy and the Challenge of Dialogue Across Difference’ in Carmel Roulston \& Celia Davies (eds.) (2000) Gender, Democracy and Inclusion in Northern Ireland, Hampshire: Palgrave.

Ridden, Jennifer ' 'The Lessons of Community Politics': The Northern Ireland Women's Coalition and the Peace Process' in Eileen Richardson (Ed.) (2001) Taking the Initiative: Women's Leadership on National Issues, Centre for Women Leaders Working Papers 2000-01, Lucy Cavendish College, University of Cambridge, pp. 103118.

Roulston, Carmel 'Feminism, Politics and Postmodernism' in Yvonne Galligan, E. Ward \& Rick Wilford (eds.) (1999) Contesting Politics: Women in Ireland North and South, Boulder: Westview Press.

Roulston, Carmel (1999) 'Inclusive Others: The Northern Ireland Women's Coalition in the Peace Process' Scottish Affairs, 26, pp. 1-13.

Roulston, Carmel \& Davies, Celia (eds.) (2000) Gender, Democracy and Inclusion in Northern Ireland, Hampshire: Palgrave, p. 3-12.

Sales, Rosemary (1997) Women Divided: Gender, Religion and Politics in Northern Ireland, London: Routledge.

Thomas, Linda \& Wareing, Shan (eds.) (1999) Language, Society and Power: An Introduction, London: Routledge.

Ward, Rachel (2004) 'Gender Issues and the Representation of Women in Northern Ireland’ Irish Political Studies, 19(2), pp. 1-20.

Ward, Rachel 'The Northern Ireland Peace process: A Gender issue?' in Chris Gilligan \& Jonathan Tonge (eds.) (1997) Peace or War? Understanding the Peace Process in Northern Ireland, Hants: Ashgate.

Wilford, Rick 'Representing Women' in Kate Fearon (ed.) (1996) 'Power, Politics, Positionings', Democratic Dialogue Papers, No.4, Belfast: Democratic Dialogue.

Wilford, Rick 'Women and Politics in Northern Ireland' in Joni Lovenduski \& Pippa Norris (eds.) (1996) Women in Politics, New York: Oxford University Press. 
Wilford, Rick 'Women, Ethnicity and Nationalism: Surveying the Ground' in Rick Wilford \& Robert L. Miller (eds.) (1998) Women, Ethnicity and Nationalism: The Politics of Transition, London \& New York: Routledge.

Wilford, Rick \& Wilson, Robin (2006) The Trouble With Northern Ireland: The Belfast Agreement and Democratic Governance, Dublin: Tasc at New Island.

Yuval-Davis, Nira (1997) Gender and Nation, London: Sage.

\section{Web Resources}

http://archive.ofmdfmni.gov.uk/publications/agreement/3.htm, The Belfast Agreement 10 April 1998, 02/06/06.

http://www.answers.com/topic/northern-ireland-assembly, 03/02/06.

http://www.ark.ac.uk/elections/flg05.htm 13/08/06.

http://www.ark.ac.uk/elections/fa03.htm 13/08/06.

http://www.ark.ac.uk/elections/fa98.htm 13/08/06.

http://www.ark.ac.uk/elections/ff96.htm 13/08/06.

\section{Interviews}

Hinds, Bronagh (2006) Interview on 04/07/06, Belfast.

Hope, Ann (2006) Interview on 04/07/06, Belfast.

Meehan, Elizabeth (2006) Interview on 27/07/06, Edinburgh.

Sagar, Pearl (2006) Email correspondence on 07/08/06.

Wallace, Patricia (2006) Interview on 05/07/06, Belfast.

Ward, Margaret (2006) Interview on 05/07/06, Belfast.

Wilford, Rick (2006) Interview on 04/07/06, Belfast.

\section{Biographical note}


Other papers published by the Centre for Advancement of Women in Politics include:

\#1 Karen Ross (2003) Women Politicians and Malestream Media: a Game of Two Sides.

\#2 Tahnya Barnett Donaghy (2003) Mainstreaming: Northern Ireland's Participative-Democratic Approach.

\#3 Kimberly Cowell-Myers (2003) Women Legislators in Northern Ireland: Gender and Politics in the New Legislative Assembly.

\#4 Celia Valiente (2003) The Politics of Prostitution: The Women's Movement, State Feminism and Parliamentary Debates in PostAuthoritarian Spain.

\#5 Elizabeth Meehan (2003) From Government to Governance, Civic Participation and 'New Politics': the Context of Potential Opportunities for the Better Representation of Women.

\#6 Paul Chaney (2003) Women and Constitutional Change in Wales.

\#7 Helena Catt (2003) How Can Women MPs Make a Difference?: Reconsidering Group Representation and the Responsible Party Mode

\#8 Gemma Carney (2004) From Women's Rights to Gender Mainstreaming: an Examination of International Gender Norms in the Republic of Ireland

\#9 Georgina Waylen (2004) What can South African transition tell us about gender and democratisation?

\#10 Paul Lambe, Colin Rallings, Michael Thrasher and Lawrence Ware (2005) Gender Imbalance in Representative Democracy: Women and Local Government in London and Birmingham 1918 2003

\#11 Susan Fountaine (2005) Who's the Boss?: The Girl Power Frame in New Zealand Papers 